Medicating Children 



\title{
Medicating Children
}

$\Leftrightarrow$ ADHD AND PEDIATRIC MENTAL HEALTH

\author{
RICK MAYES
}

CATHERINE BAGWELL

JENNIFER ERKULWATER

HARVARD UNIVERSITY PRESS

Cambridge, Massachusetts, and London, England 2009 
Copyright $@ 2009$ by the President and Fellows of Harvard College

All rights reserved

Printed in the United States of America

Library of Congress Cataloging-in-Publication Data

Mayes, Rick, 1969-

Medicating children : ADHD and pediatric mental health / Rick Mayes, Catherine Bagwell, Jennifer Erkulwater.

p. ; cm.

Includes bibliographical references and index.

ISBN-13: 978-0-674-03163-0 (alk. paper)

1. Attention-deficit hyperactivity disorder-Chemotherapy-United StatesHistory. I. Bagwell, Catherine. II. Erkulwater, Jennifer L. III. Title.

[DNLM: 1. Attention Deficit Disorder with Hyperactivity-drug therapy.

2. Central Nervous System Stimulants—adverse effects. 3. Child. 4. Drug Therapy—ethics. 5. Health Policy. 6. Mental Health Services.

WS 350.8.A8 M468m 2009]

RJ506.H9M4234 2009

362.198'928589-dc22

2008007899 